\title{
Analyzing English Phrases from Pāninian Perspective
}

\author{
Akshar Bharati, Sukhada, and Dipti M Sharma \\ Language Technologies Research Centre, \\ IIIT Hyderabad, Telangana 500032, India \\ sukhada@research.iiit.ac.in \\ dipti@iit.ac.in
}

\begin{abstract}
This paper explores Pāninian Grammar (PG) as an information processing device in terms of 'how', 'how much' and 'where' languages encode information. PG is based on a morphologically rich language, Sanskrit. We apply PG on English and see how the Pāninian perspective would deal with it from the information theoretical point of view and its effectiveness in machine translation.

We analyze English phrases defining sup (nominal inflections) and tin (finite verb inflections) and compare them with the notion of pada (an inflected word form) and samasta-pada (compound) in Sanskrit.

Sanskrit encodes relations between nouns and adjectives and nouns in apposition through agreement between gender, number and case markers, whereas English encodes them through positions. As a result, constituents are formed. It appears that an English phrase contains more than one pada, hence, cannot be similar to a pada. However, we show the linguistic similarities between a pada, samasta-pada and 'phrase'.
\end{abstract}

\section{Introduction}

Languages encode linguistic information in terms of explicit markers or positions of the words. This inspires us to analyse how a source language syntax encodes linguistic information, so that it can be transfered to target language. Pāninian Grammar (PG) gives insights to explore 'how', 'how much' and 'where' languages encode linguistic information [6]. In this paper, we use concepts from PG and apply them to English and show how it can help in machine translation (MT).

PG analyses a word as a combination of 'root' (prakrti) and 'suffix' (pratyaya) [9]. Pānini uses the term pada for the words that are ready to participate in a sentence. A pada contains explicit information about a word's semantic relation with other words in a sentence.

The word derivation process in PG takes a nominal stem and/or a verbal stem as the basic input and terminates the process with the derivation of pada [22]. Since a pada is formed with respect to an actual sentence structure, it is called the highest derivative and is a syntactic unit rather than a morphological unit in the Pạninian system [22]. 
Sanskrit uses two different terms, śabda and pada, both of which are roughly translated as 'word' in English. In Sanskrit, śabda is used for linguistic expressions ranging from an individual speech sound to an utterance [23], whereas, a pada is a primary syntactic unit that appears in a sentence. In other words, the difference between a śabda and a pada is that of a 'word' and its 'fully inflected forms' [18]. A śabda/word is a language unit such as lexeme, word or word form whereas a pada is a word form that has inflected to mark its semantic relation with other words. Pāṇini categorizes a pada into two classes: 1) subanta and 2) tinanta $[21,8]$.

1. Subanta: A subanta class includes the participants of a sentence which inflect for marking various semantic relations. A subanta is formed by suffixation of nominal inflections called sup ${ }^{1}$.

The subanta class includes all nouns, pronouns, adjectives and adverbs etc. in it. Since, adverbs are indeclinables, they do not inflect for any case. That is why adverbs do not seem to carry any sup on surface. The sūtra (A.2.4.84) deletes the inflections attached to the adverbs. It suggests that at some point of time, adverbs also had been inflecting like other nominals. Hence, adverbs also fall in the subanta class.

2. Tinanta: This class includes words which mark some semantic relations and finiteness of the verb. In Sanskrit, verbs take $\operatorname{tin}^{2}$ suffixes to express tense, number, person, mood and voice. Similarly, in English, the auxiliaries and modal verbs when attached to a verb express tense, number, etc. hence correspond to tin.

The primary objective of analyzing a sentence is to identify what role each part is playing. The role of the finite verb becomes important with relation to other participants. Therefore, Pānini takes only two classes.

Though this classification is mainly based on the surface realization of the words in Sanskrit, Pānini's concepts of grammar are not specific to Sanskrit. The concepts are rather generic and can be applied to other languages. The major theoretical concepts from PG would directly apply on other agglutinative languages, languages similar to Sanskrit. However, they can be extended to other languages as well.

In Sanskrit, the nominal inflections sup and the finite verb inflections tin are realized through suffixation. However, the syntactic mechanisms for marking the semantic relations across words in a sentence might be different in different languages. Some languages such as Persian might have prepositions, some might have other kind of syntactic devices. For example, in Hindi, the relations of a noun to the verb or other nouns are marked through postpositions. From the Pāninian perspective, a pada in Hindi would be 'noun+postposition' [5].

\footnotetext{
${ }^{1}$ Sup is the acronym formed from the first and the last phoneme of the list of nominal suffixes.

2 Tin is the acronym formed from the first and the last phoneme of the list of verbal suffixes.
} 
Sanskrit has a grammatical rule apadam na prayuñjita [11] which says: "a word which is not a pada should not be used in a sentence" [8]. Sobin's statement that "only phrases may be sentence fragments" [24] imposes a constraint similar to the statement apadam na prayuñjita for English. It is alluring to compare the two concepts pada of Sanskrit and 'phrase' of English.

Application of PG to other languages and finding out its effectiveness for machine translation (MT) is the task on hand. In this paper, we look at English from the Pāninian perspective. We investigate equivalent mechanisms of sup, tin and pada in English phrases and compare them with the notions of pada and samasta-pada (compound) in Sanskrit.

We talk about the related work in Section 2. Section 3 describes the necessary conditions for pada formation according to PG. Section 4 defines sup, tin for English and compares English phrases with the notions of pada and samasta-pada in Sanskrit. Section 5 shows a continuum between phrases and compounds. Section 6 shows how complex phrases are handled using the Pạninian perspective. Section 7 concludes the paper.

\section{Related Work}

Gangopadhyaya has analyzed noun phrases in Bengali and studied assignment of role and the kāraka theory following the Indian grammatical tradition. According to her: "The term phrase corresponds to the term pada in its minimal form but not in its expanded form, i.e. when a phrase is understood as a syntactic constituent consisting of more than one word." According to her, a single word phrase corresponds to a pada but a phrase that consists of more than one word does not correspond to a pada [12].

Gangopadhyaya does not account for phrases which consist of multiple words such as "brave soldiers", "very intelligent boy", etc.

According to Apte [2], the expression of a single idea is a word (pada) and the aggregation of two or more words without a subject or predicate is a phrase (padasamuccaya).

Apte calls a phrase as padasamuccaya, but does not give any linguistic account for it. He looks at Sanskrit from the English perspective, and therefore interprets a phrase as a group of multiple padas. But if we look at English from the Pāninian perspective, we find that a minimal/simple phrase corresponds to a pada or a samasta-pada. And, a complex phrase that is composed of two or more phrases corresponds to a padasamuccaya.

Local Word Grouping (LWG) [5] is a notion similar to pada found in literature. In LWG, word groups are formed on the basis of local (adjacent) word information for Indian languages.

Our assessment is based on flow of information where word groups are formed on the basis of neighboring syntactic inflections called sup and tin for any language. This is grammatically more precise and also allows to find out syntactic elements that unite the words of a sentence into a meaningful unit. 
To the best of our knowledge, we have not found any work that analyzes English phrases from the Pāninian perspective.

\section{Samartha Theory of Pānini and its Relation to Pada and Phrase Formation}

Pānini's samartha theory stands as a fundamental principle for any semantic and syntactic operation. According to Pānini, no grammatical operation can take place, be it pada formation or sentence formation, until and unless they qualify the condition of being samartha [21]. Thus the concept of sāmarthya ${ }^{3}$ is a fundamental principle for any grammatical operation in a language string. The word samartha is used in the following two meanings:

1. Ekārthībhāva sāmarthya: It says that 'formation of a pada depends on unity of meaning' [26]. In this case, the padas having direct semantic relation become one pada as in compounds and primary and secondary derivatives. Here the word samartha means "organized together" (samgatārtham samartham and "fused together" (samsrsțtartham samartham) [17]. The objective of ekārthībhāva sāmarthya is to present compounds as one pada (ekapada) or one unit.

2. Vyapekșā sāmarthya (meaning-interdependence): It says that "any operation pertaining to padas takes place if and only if the padas have direct semantic connection" [26]. In this case, samartha means "seen together" (samprekșitārthah samarthah) and "bound together" (sambaddhārthah samarthah) [17]. For example, subject, verb, object etc. are seen bound together in a sentence. The objective of vyapekșa sāmarthya is to show sentence as one unit. Padas seem to carry diverse meanings but a sentence indicates a single meaning.

For a word to stand in a syntactic structure, it is necessary to pass through one of these sāmarthyas.

Let us take the Sanskrit sentence (1) and examine how Pānini captures the flow of information through his grammar.

$$
\begin{aligned}
& \text { Vīrāḥ sainikāḥ des̀am rakṣanti } \\
& \text { brave.PL,NOM soldier.PL,NOM country.SG,ACC protect.PR,3,PL } \\
& \text { 'Brave soldiers protect the country.' }
\end{aligned}
$$

In (1), the word raksanti is a tinanta pada. It is composed of the verbal base raks and a tin inflection namely -anti. A tin inflection is assigned to a verb with respect to its compatibility (sāmarthya) with the doer/agent or theme/patient of the action. In the active voice, the tin suffixes express the doer/agent of the action through agreement. The suffix - anti denotes active voice, third person, plural. When the doer is expressed by a tin suffix, the sūtra (A. 2.3.46) [27] assigns nominative case (pratham $\bar{a}$ vibhakti) to the doer to express nominal stem

\footnotetext{
${ }^{3}$ The words samartha and sāmarthya are used interchangeably in Sanskrit grammar.
} 
meaning (prātipadikārtha), gender (linga), or number (vacana) etc., of the doer. This also makes the nominal a subanta pada.

In (1), the words sainikāh and vīra $h$ are marked with nominative case (prathamā vibhakti) and plural number. The agreement between the verb raksanti and nominal sainikạh (soldiers) indicates that the pada sainikāh plays the role of the doer/agent of the action raksanti (protect).

Having the same vibhakti, the words sainikāh and vīrăh express the modified and modifier relation between them and also confirm semantic compatibility (sāmarthya) among them.

The theme/patient des̀m (country) is marked with the sup, -am (accusative case, singular number). It makes des̀am (country) a subanta pada.

From the above description, it is clear that a pada is a syntactic unit that takes a nominal or a verbal inflection called vibhakti, which explicitly marks the semantic relation of a word with another participant. In some cases, the vibhakti can also be NULL (zero) but it has to be present.

\subsection{Sāmarthya and Phrase Formation}

While looking at samartha theory and the concept of phrase in English, we observed that both the theories capture the same aspect of language but in slightly different ways. They both capture the coherence of words together in a well formed syntactic structure. As per English grammar, a phrase is a sequence of words or sometimes a single word that functions as a single unit within a sentence $[19,16]$. The words that are closely related to each other form a syntactic constituent. As per samartha theory, for a word to become a pada or to form a word group with other word/s such as in compounds, it has to have direct semantic relation with the other words in the sentence. This relates to the semantic relation among padas in a sentence and between the members of a compound.

According to the sūtra samarthah padavidhih (A. 2.1.1), any operation concerning to inflected word form/s $(p a d a / s)$ i.e. padavidhi takes place if and only if there exists a semantic connection. So is true for constituent formation. Words in a sentence do not occur in isolation rather they form groups on the basis of their relationship with other words. Thus, the notion of pada, though developed for Sanskrit which has a rich inflectional and derivational morphology, can be applied to any language. If we apply it to English which is morphologically not so rich, we have to analyze English sentences from the Pāninian perspective, especially in terms of sup and tin and pada and samasta-pada or ekārthībhāva sāmarthya (single integrated meaning) and vyapekșā sāmarthya (meaning-interdependence).

\section{Subanta Pada and Tinanta Pada in English}

In Sanskrit, sup carries information of number and the case marker. However, English has different sets of morphemes for marking number and case information. In English, the number information is marked through a suffix '-s' for 
plural and '-0' (NULL) for singular and the case is realized through prepositions or through 'generalized vibhakti' $[3,4]$ in terms of the position of the subject or object [1]. For example, in "to the boy" and "to the boys", the preposition "to" marks case information and the inflection "s" marks number information.

In English, the tin inflections are realized through auxiliaries and modal verbs. The tin suffixes also express the role of one of its participants through agreement.

Attachment of a nominal or a verbal inflection to a nominal or verbal entity makes it a subanta or a tinanta pada respectively.

Let us take the English sentences in (2) and analyse it using Pāṇinian primitives such as sup, tin and pada.

(2) She gave books to Mohan.

Figure 1 shows the constituency tree diagram for sentence (2). The prepositional phrase "to Mohan" carries preposition "to" as a sup, hence, it corresponds to a subanta pada. The verb gave has -ed as a tin suffix, hence it can be considered a tinanta pada.

The words "She" and "books" are the subject and object respectively and do not seem to have any explicit case marker. Bharati et al $(1996,1998)$ have shown that English has the notion of 'generalized vibhakti' which corresponds to the sup suffixes in Sanskrit. The 'generalized vibhakti' is realized either through subject $^{4}$ or object positions or through prepositions. Thus in sentence (2), She occurring at the subject position seems to carry no sup, but according to Bharati et al. $(1996,1998)$, since it occurs at the subject position, it carries a generalized vibhakti in terms of subject position, hence, it is a subanta pada. Similarly, the object "books" carries a generalized vibhakti in terms of object position, hence, it is also a subanta pada. See Figure 1, where each box represents an independent pada.

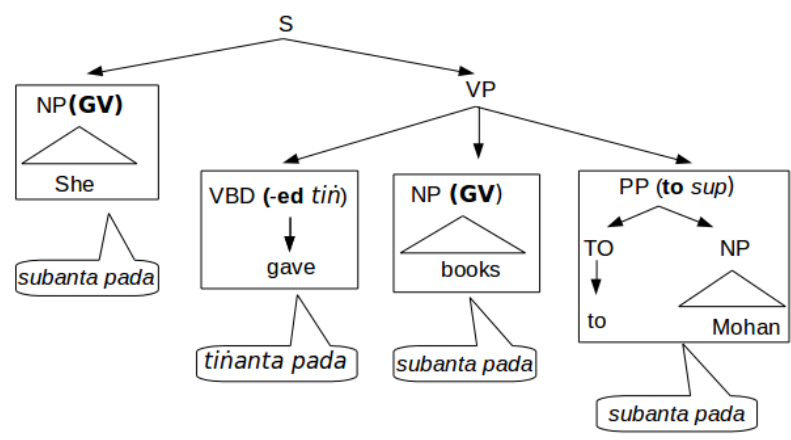

Fig. 1. Pada information in tree diagram for (2). In this figure GV stands for 'generalized vibhakti'

\footnotetext{
${ }^{4}$ In linguistics, the notion of subject in ILs is much debatable [7].
} 
In sentence (2) each phrase consists of a single lexical item, therefore, we can say that a phrase with a single lexical item corresponds to a pada from the Pāninian perspective. But a phrase is not always a single word.

A phrase is defined as a word or a sequence of words that functions as a single unit within a clause/sentence $[16,19]$. Given this definition, how would PG handle a phrase that consists of more than one word? For instance,

(3) Four things scientists have been exploring about the incredibly awesome moon.

In sentence (3), the word group "four things", and "scientists" are NPs; "have been exploring about the incredibly awesome moon" is a VP which consists of a finite verb group, and a prepositional phrase. From the above description, one can say that the NP, "scientists" being at subject position carries a sup in term of subject position. So, "scientists" is treated as a pada. The verb group "have been exploring" contains "explore" as a verb and "have_been_ing" as a tin. So, "have been exploring" is treated as a tinanta pada. But what about the NP "four things" which consists of more than one word and does not have any preposition to mark it a pada? And, what about the prepositional phrase "about the incredibly awesome moon" which though has a preposition/sup but at the same time contains one more phrase in it, the adjectival phrase (ADJP) "incredibly awesome"? How many padas should we consider in the constituents "four things" and "about the incredibly awesome moon"? In order to resolve such issues, let us first look at the characteristics of Sanskrit compounds (samastapada).

\subsection{Four Characteristic Features of the Compounds (samasta-pada)}

A Sanskrit compound has following four characteristic properties:

1. Sublopa (elision of internal sup/vibhakti): Elision of internal sup as opposed to an asamasta-pada (sentence) takes place in a samasta-pada. An uncompounded word group is also called vākya (sentence) in Sanskrit. Only the final element receives case inflection in compounds. For example, the genitive case marker (sasțhî-vibhakti) is deleted in the samasta-pada rājapurusah (kingman), whereas in the uncompounded word group rājñah purusạ (king's man), the genitive case marker is not deleted.

2. Avyavadhāna (no intervention by other word (pada)): Intervention by any other word (pada) does not take place in a samasta-pada but in an uncompounded word group it can take place. For example, one can say rājñah rddhasya purusah (man of a rich king), where rājñah purușah has been intervened by r. $d$ dhasya a modifier of rājna cannot modify rājñah. One cannot say *räja-rddhasya-puruṣah.

3. Niyatapaurvāparya (fixed word order): The words in a samāsa occur in a fixed order. But in a sentence the padas can occur freely; rājñah purusah or purușo rājñah 
4. Aikasvarya (accent/stress): All the words in a samasta-pada have only one accent/stress. For example, in räjapurusah the stress is on the final vowel / syllable, but in a sentence, rājñah puruṣah, both the words are stressed independently.

Having looked at the characteristic properties of samasta-pada (compounds), let us now look at the English phrases and see whether they are comparable with samasta-pada or not. Most phrases have all the four properties listed above. We will examine them one by one. For example,

No internal preposition/sup is present between the words in the phrase "four things". Thus, the absence of a vibhakti suggests that the internal preposition must have been deleted. So, there is a sublopa.

No other phrase can occur within a phrase, i.e. we cannot say "*four to explore things". So, the phrase has avyavadhāna feature of compounds.

The words have fixed order. One cannot say "things four". So, they follow the principle of niyatapaurvāparya.

In English, stress is on the first word in common phrases and on the noun in descriptive phrases. Table 1 shows stress variations in common and descriptive phrases. The words in bold have stress in these phrases ${ }^{5}$.

Table 1. Showing stress variations for common and descriptive phrases.

$$
\begin{array}{l|l}
\text { Common phrase } & \text { Descriptive phrase } \\
\hline \text { a sports car } & \text { a small car }
\end{array}
$$

In our example, in the phrase "four things", the stress is on 'things', 'four things'. So, there is aikasvarya.

Being able to see the similarities between a phrase and samāsa/samasta-pada (compound) only tells us that the components of a phrase have some semantic relation among them. But, even for a compound to participate in a sentence, it has to become a pada. It should have some vibhakti to express its relation with other participants of the sentence.

It seems that the phrase "four things" neither has any overt vibhakti nor any generalized vibhakti. Then, how would it pass the test of being a pada?

In (3), the verb "explore" has two arguments. One argument is represented by the subject "scientists". But the second argument represented by "four things" is not at the object position. It has moved leftward to the initial position of the sentence for topicalization [16]. The NP "four things" originated at the object position of "explore" leaves a trace at object position which encodes the relation of the moved element. To put it in other words, the topic position also assigns vibhakti to the topicalized constituent. Thus, the NP "four things" has its generalized vibhakti in terms of topic position and that is why it is a pada.

\footnotetext{
${ }^{5}$ See "Learn English with Speak Method, URL: www.speakmethod.com/syllablestresssetphrases.html"
} 
In the PP "about the incredibly awesome moon", it is not the case that an external element/phrase "incredibly awesome" has intervened between "the" and "moon" hence, there is a violation of one of the compounding characteristics called avyavadhāna. Rather, it is an example of embedded compounding. Here, first the words "incredibly" and "awesome" form a compound and then the compound "incredibly awesome" forms another compound with the words "the" and "moon". After that, the compound "the incredibly awesome moon" takes the preposition "about" as a sup which makes it a pada.

To summarize, we can say that the constituent "scientists" in sentence (3) occurs at the subject position, hence, as stated by Bharati et al. (1996,1998), it carries a 'generalized vibhakti' in terms of subject position. The NP "four things" gets its sup inflection from its trace at object position. Also, if the constituent "four things" occurs in a prepositional phrase, both the words take only a single preposition as in I gave you money for four things. Therefore, the whole group, "four things" will be treated as a single subanta pada. The phrase "about the incredibly awesome moon" can also be taken as a subanta pada which carries the preposition "about" as a sup.

From the above observations, we can say that complex English phrases come close to compound constructions in Sanskrit, except that in Sanskrit, a compound becomes a single word whereas in English, the phrasal components maintain multiple word status. This hardly matters. Because, compound constructions in English cover a whole range of written styles such as one word as in "milkman" (man who delivers milk), hyphenated as in "milk-fever" (disease caused by lack of the calcium contained in milk) and with white space as in "milk bottle" (bottle for containing milk). Hence unlike Sanskrit, ekapadībhāva [20] 'becoming one word' of more than one words is not a characteristic property of English compounds. In fact in [14] and [13], Giegerich argues that the distinction between compound and phrase is neither necessary nor possible in English. Therefore, simple English phrases can be treated as padas.

So, we can say that English phrases share the properties of a compound to some extent. However, unlike Sanskrit compounds, they maintain more than one word status. Thus, they are not compounds in the strictest sense. Therefore, we call them 'quasi-compounds' (ardhasamāsa).

We have already seen that in (1), the modifier and modified relation between vira $\bar{a}$. (brave) and sainika $h$ (soldiers) is expressed by attachment of the same case marker to both the words. Similarly, if the head sainika takes some other case marker to express its relation, the modifier vìra also takes the same case marker such as vīrān sainikān (to brave soldiers), vīrebhyah sainikebhyah (for brave soldiers), vīrānām sainikānām (of brave soldiers) etc.,. On the other hand, English attaches a single preposition to all the members of the constituent "brave soldiers": "by brave soldiers", "for brave soldiers", "of brave soldiers". As a result the positions of the constituent members get fixed and phrases are formed.

As explained in Section 1, a tinanta pada is formed by adding tin inflections to the verbal bases. 
As mentioned in Section 4.1, intervention of any external word/pada is not allowed in a samasta-pada but the finite verb groups are exceptions to this condition, where an adverbial phrase can intervene in a finite verb group. For example, take the expression in (4):

(4) 'have been slightly changed'

In (4), the adverb "slightly" is embedded in the tinanta pada, "have been changed". But then, since a tinanta pada is not a compound, other words can intervene.

It should be noted that except adverbs, no other words can intervene in a tinanta pada. That is why, the expressions like: "*have to operate been changed", "*have been to operate changed", "*have been to Paul changed", etc., become ungrammatical.

Identification of tinanta padas helps in forming a verb group whereby translation of verb and its suffixes can be handled properly.

\section{Spectrum of Flexibility in Compounds}

If we look at the various types of expressions, there appears to be a continuum from 'flexible' expressions to completely 'fixed' expressions in compounds. For example, in Sanskrit, janușāndhah (blind from birth, born blind), alpānmuktah (loosed from a little distance), vācoyuktih (appropriate speech) etc., are some of the expressions where there is no deletion (lopa) of the internal sup vibhaktis and the compound meaning is similar to that of the canonical phrasal paraphrase (vigraha-vākya) [15].

Presence of a vibhakti expresses the relation between words. In compound expressions, internal vibhaktis and number information are not so important $[2,25,26]$. The relations among members of a compound are expressed through positions of the words. That is why vibhaktis can vanish. Even in expressions like stokānmuktah (loosed from a little distance), gosucarah etc., where the internal vibhakti is not deleted, we use the same expression stokānmuktah, even if we wish to say stokābhām muktah (dual) or stokebhah muktah (plural) [26].

In rājapurusah etc., even after deletion of the internal sup, the potency of the sup takes place by pratyayalaksana (A.1.1.62), that is, the operations pertaining to a suffix take place even after deletion of the suffix [27]. Therefore, the component rājan is treated as a pada for morphological operations, as a result elision of the letter $n$ by (A. 8.2.7) can be seen on the surface. Expressions like brāhmanakambalah, yūpadāru etc., also undergo similar operations but no effect of the internal sup can be structurally seen on the surface. In such expressions, the compound meaning is similar to their components and one can construct synonymous compounds using synonyms. For instance, rājabhrtyah is the paraphrase of rājapurusah and dvijakambalah is the paraphrase of brāhmanakambalah.

On the other hand, there are expressions like krșnasarpah which are completely inflexible. These expressions have all the characteristics of compounds 
Analyzing English Phrases from Pinian Perspective

Table 2. Showing flexibility spectrum in Sanskrit expressions

\begin{tabular}{|c|c|c|c|}
\hline & aluksamāsa & samāsa & nityasamāsa \\
\hline & $\begin{array}{l}\text { vācoyuktih (appro- } \\
\text { priate speech) }\end{array}$ & $\begin{array}{l}\text { rājapuruṣah } \\
\text { (king-man) }\end{array}$ & $\begin{array}{l}\text { krṣnasarpah } \\
\text { (cobra) }\end{array}$ \\
\hline sup-deletion (sublopa) & $\mathrm{X}$ & $\checkmark$ & $\checkmark$ \\
\hline un-interruption (avyavadhāna) & $\checkmark$ & $\checkmark$ & $\checkmark$ \\
\hline fixed order (niyatapaurvāparya) & $\checkmark$ & $\checkmark$ & $\checkmark$ \\
\hline one accent (aikasvarya) & $\checkmark$ & $\checkmark$ & $\checkmark$ \\
\hline one word & $\checkmark$ & $\checkmark$ & $\checkmark$ \\
\hline paraphrasing & $\checkmark$ & $\checkmark$ & $\mathrm{x}$ \\
\hline
\end{tabular}

but irrespective of the meanings of the words involved in compounding the expressions give a more specialized meaning. In our example, the compounding words krsna (black) and sarpa (snake) leave their meanings and give the special meaning "cobra". Paraphrasing is also not possible in such cases. Such compounds are called nityasamāsa (completely fixed expressions). Table 2 gives an overview of spectrum in Sanskrit compounds. It illustrates the four afore mentioned compound properties plus 'one word', 'multiple word' status and 'paraphrasing' with examples where, you will notice that as one moves from left to right the degree of flexibility of the expressions varies.

\subsection{Flexibility Spectrum in English Compounds}

We claim that all languages including English have flexibility spectrum in compounding. In English, the level of variation is similar to Sanskrit or even higher. We have already seen that English phrases fall under 'quasi-compound' class. The 'quasi-compounds' show the highest degree of flexibility in English.

Instances of aluksamāsa are also found in English. For example, in "kinsman" (a blood relative, especially a male), marksman" (a person who is skilled in shooting at a mark) etc., the compound members "kins" and "marks" are possessive forms "kin's" and "mark's" [10]. The possessive suffix "-'s" does not vanish in compound forms.

The compounds like "blackbird" denoting a bird of a particular species [10] fall under nityasamāsa class because such compounds give a very specialized meaning different from the compound members.

Table 3 shows the flexibility spectrum in English compounds.

\section{Handling Complex Phrases from The Pāninian View Point}

After finding evidence for simple phrases, it is time to move towards more complex phrases such as "the symbol of mature wisdom", where the phrase is composed of two different phrases: an NP "the symbol" and a PP "of mature wisdom". Or other complex phrases such as "the boy who came from Delhi yesterday", where the noun phrase is composed of an NP and a relative clause. The 
Table 3. Showing flexibility spectrum in English expressions

\begin{tabular}{lcccc}
\hline & ardhasamāsa & aluksamāsa & samāsa & nityasamāsa \\
\hline & a good boy & $\begin{array}{l}\text { kinsman, } \\
\text { marksman }\end{array}$ & $\begin{array}{l}\text { lawn tennis, blackbird } \\
\text { bird-cage, } \\
\text { football }\end{array}$ \\
\hline sup-deletion (sublopa) & $\checkmark$ & $\mathrm{x}$ & $\checkmark$ & $\checkmark$ \\
un-interruption (avyavadhāna) & $\checkmark$ & $\checkmark$ & $\checkmark$ & $\checkmark$ \\
fixed order (niyatapaurväparya) & $\checkmark$ & $\checkmark$ & $\checkmark$ & $\checkmark$ \\
one accent (aikasvarya) & $\checkmark$ & $\checkmark$ & $\checkmark$ & $\checkmark$ \\
one word & $\mathrm{x}$ & $\checkmark$ & $\checkmark$ & $\mathrm{x}$ \\
multiple word & $\checkmark$ & $\mathrm{x}$ & $\checkmark$ & $\mathrm{x}$ \\
paraphrasing & $\checkmark$ & $\checkmark$ & & $\checkmark$ \\
\hline
\end{tabular}

clause in its turn has multiple phrases in it. As shown above, all the member phrases of a complex phrase fall under the subanta or tinanta pada class.

The PP "of mature wisdom" has a direct semantic connection with the NP "the symbol".

The minimal phrases forming a complex phrase are seen bound together. That is why the tests like movement and substitutions etc. apply to the entire complex phrase and as a result the whole phrase moves bound together or is substituted as a whole and represents a single meaning which we call ekārtha. The fact that the entire complex phrase comes under the scope of a single preposition (sup) suggests that the entire complex phrase represents one unit.

Since a complex phrase is composed of two or more phrases/padas and all the padas maintain their padaness i.e. the subantaness (subantatva), one can not say that a complex phrase is a pada. The name we've given to such phrases is subantamukhyaviśesyaka-ekārthaka-padasamuccaya. It means a group of phrases (padasamuccaya) which has a single meaning (ekārthaka) where a subanta pada is the head of that particular complex phrase (subantamukhyaviśesyaka). The hierarchic organization (internal phrasal structure) within a sentence also supports the subantamukhyaviśeșyaka-ekārthaka-padasamuccaya view.

The concept of vyapekșā sāmarthya in Pāninini is a general principle to capture meaning interdependence in a sentence. It not only captures the meaning interdependence among nominals but also connects the subanta padas with the tinanta pada. This generality of vyapekșā sāmarthya might seem to be overcovering the VPs also but the element subantamukhyavisesyaka in the term subantamukhyaviśeșaka-ekārthaka-padasamuccaya restricts it only to the subanta padas.

Identification of padas helps in the demarcation of syntactic units in a sentence. Once the syntactic units are identified, source language to target language generation becomes easy, especially, when target language is morphologically richer than the source language, such as Hindi and English. Similar to English, Hindi also has 'quasi-compounds' phenomenon. For instance, let us take the expressions in (5). 


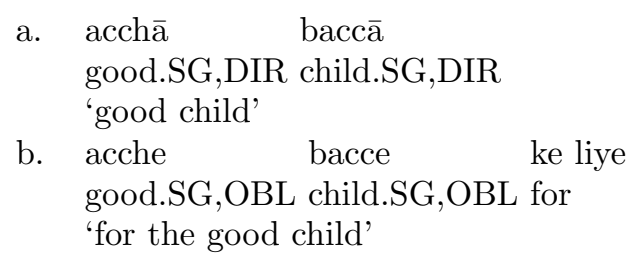

In (5-a), neither of the words has any case marker, therefore, both the words are in direct case [5]. But in (5-b), the head baccā (child) has the case marker ke liye attached to it. So, the head baccē (child) is in oblique case. Since no covert case marker is present after the adjective acche, it should be in direct case. But that is not true in this case. But if we consider it to be a 'quasi-compound', we can say that sublopa (elision of internal case marker/sup) has taken place in this expression. And, by the principle of pratyayalaksana, the operations pertaining to sup takes place. Hence, the modifier acche is in the oblique case.

Identification of syntactic units is also helpful in reordering partially free word order language [8].

\section{Conclusions}

We have analyzed English phrases based on the Pāninian perspective. We have defined nominal inflection sup, and finite verb inflections tin for English and compared English phrases with the notion of pada and samasta-pada in Sanskrit. We have shown that a single word phrase directly corresponds to the concept of pada in Sanskrit and a complex English phrase (a phrase consisting of more than one word) corresponds to compounds. The study shows that the insights from Pāninian Grammar can be used to analyze any language from information theoretic point of view. We have also briefly shown its effectiveness in machine translation.

Acknowledgments. We are immensely grateful to Prof. Vineet Chaitanya for sharing his insights and for his continuous guidance during this research. We would also like to thank Prof. Amba P Kulkarni for the discussions in the early stage of the research, to Sirisha Manju, Roja Laxmi and Mahalaxmi for their assistance in implementation of the concepts for English-Hindi machine translation, to Pratibha Rani for her comments on an earlier version of the manuscript, and to Prof. Aditi Mukherjee and Prof. Shatrunjay Rawat for their feedback on the final version of the paper. However, we have not yet fully incorporated their comments into this version of the paper, we wish to incorporate them in future versions of the paper.

\section{References}

1. Anantpur, A.P.: Anusaaraka: An approach for MT taking insights from the Indian Grammatical Tradition. Ph.D. thesis, University of Hyderabad (2009) 
2. Apte, V.S.: The student's guide to Sanskrit composition. Chowkhamba Sanskrit Series Office (1963)

3. Bharati, A., Bhatia, M., Chaitanya, V., Sangal, R.: Paninian grammar framework applied to English. Department of Computer Science and Engineering, Indian Institute of Technology, Kanpur (1996)

4. Bharati, A., Bhatia, M., Chaitanya, V., Sangal, R.: Paninian grammar framework applied to english. South Asian Language Review 8(1), 1-23 (1998)

5. Bharati, A., Chaitanya, V., Sangal, R.: Natural language processing: a Paninian perspective. Prentice-Hall of India New Delhi (1995)

6. Bharati, A., Kulkarni, A.: Information coding in a language: Some insights from pāṇinian grammar. Dhiimahi, Journal of Chinmaya International Foundation Shodha Sansthan I(1), 77-91 (2010)

7. Bharati, A., Kulkarni, A.: 'subject' in English is abhihita (2011)

8. Bharati, A., Sukhada, Jha, P., Paul, S., Sharma, D.M.: Applying sanskrit concepts for reordering in MT. In: Proceedings of the ICON2015 (2015)

9. Bharati, A., Sukhada, Sharma, D.M., Paul, S.: Sanskrit and Computational Linguistics, chap. Anusāraka Dependency Schema from Pāṇinian Perspective. D. K. Publishers (2015)

10. Bloomfield, L.: Language. Motilal Banarasidass Publishers Private Limited, Delhi (1994)

11. Dvivedi, K.: Rachanānuvādakaumudī. Vishwavidyalaya Prakashan (1953)

12. Gangopadhyay, M.: The noun phrase in Bengali: Assignment of role and the kāraka theory. Motilal Banarsidass Publishers. (1990)

13. Giegerich, H.: How robust is the compound-phrase distinction? stress evidence from bi-and tripartite constructions in english. Linguistics 2, 65-86 (2008)

14. Giegerich, H.J.: Attribution in English and the distinction between phrases and compounds (2006)

15. Gillon, B.S.: Exocentric (bahuvrīhi) compounds in Classical Sanskrit. In: Proceedings, First International Symposium on Sanskrit Computational Linguistics. pp. $1-12(2007)$

16. Haegeman, L., Guéron, J.: English grammar: A generative perspective. Blackwell Oxford, England (1999)

17. Joshi, S.: Patanjali's vyakarana-mahabhasya. Samarthahnika (1968)

18. Kapoor, K.: Dimensions of Pānini Grammar: The Indian Grammatical System. DK Printworld (2005)

19. Kroeger, P.R.: Analyzing grammar: An introduction. Cambridge University Press (2005)

20. Mahavir: Pāṇini as Grammarian: With Special Reference to Compound Formations. Bharatiya Vidya Prakashan (1978)

21. Mahavir: Samartha Theory of Pānini and Sentence Derivation. Munshiram Manoharlal Publishers (1984)

22. Sharma, R.N.: The Aștādhyāȳ̄ of Pānini: Introduction to the Aștādhyāȳ̄ as a Grammatical Device, vol. 1. Munshilal Manoharlal Publishers (1987)

23. Singh, J.D.: Pāṇini, his description of Sanskrit: An analytical study of Aṣtāàdhyāyī. Munshiram Manoharlal Publishers (1991)

24. Sobin, N.: Syntactic analysis: the basics. John Wiley \& Sons (2010)

25. Speijer, J.S.: Sanskrit Syntax. Motilal Banarsidass (1886)

26. Varma, S.: Vyākaraṇa K̄̄ Dārs̀anika Bhūmikā. Munshiram Manoharlal, New Delhi (1971)

27. Vasu, S.C.: The Aṣṭādhyāȳ̄ of Pāṇini. Motilal Banarsidass Publishers (1996) 